\title{
PENGARUH KUALITAS AUDIT DAN KEPEMILIKAN INSTITUSIONAL TERHADAP COST OF DEBT (Studi Empiris Pada Perusahaan Manufaktur Yang Terdaftar Di BEI Periode 2012-2015)
}

\author{
Anton Robiansyah ${ }^{1}$, Dwi Novita ${ }^{2}$, Furqonti Ranidiah ${ }^{1}$ \\ 1Program Studi Akuntansi Ekonomi Universitas Muhammadiyah Bengkulu \\ ${ }^{2}$ Sekolah Tinggi Ilmu Ekonomi Syariah Nahdatul Ulama \\ antonrob@umb.ac.id,dwinovitaekis@gmail.com,furqonti.ranidiah@gmail.com
}

\begin{abstract}
ABSTRAK
Anton Robiansyah, Dwi Novita, Furqonti Ranidiah; Penelitian ini bertujuan untuk menganalisis pengaruh kualitas audit dan kepemilikan institusional terhadap cost of debt. Populasi dalam penelitian ini adalah seluruh perusahaan manufaktur yang terdaftar di BEI tahun 2012-2015. Jenis penelitian yang digunakan dalam penelitian ini adalah penelitian empiris. Teknik pengambilan sampel yang digunakan adalah purposive sample dan terpilih 72 perusahaan unit analisis. Alat analisis data dalam pengujian ini menggunakan OLS (ordinary least square), dimana ingin melihat pengaruh kualitas audit dan kepemilikan institusional terhadap cost of debt.

Berdasarkan hasil dari penelitian ini menunjukkan bahwa kualitas audit berpengaruh negatif terhadap cost of debt dengan tingkat signifikansi 0.014 yang berarti bahwa perusahaan yang memilih KAP BIG4 yang memiliki reputasi yang baik dan ini dipandang sebagai hal positif bagi pihak kreditur. Sedangkan kepemilikan institusional tidak berpengaruh terhadap cost of debt dengan tingkat signifikansi 0.847 menunjukkan bahwa ada atau tidaknya kepemilikan institusional perusahan - perusahaan di Indonesia tidak mempengaruhi hubungan kepemilikan intitusional dan biaya utang.
\end{abstract}

\section{ABSTRACT}

Anton Robiansyah, Dwi Novita, Furqonti Ranidiah; This study aims to analyze the effect of audit quality and institutional ownership on the cost of debt. The population in this study are all manufacturing companies listed on the Stock Exchange in 2011-2014. The type of research used in this study is empirical research. The sampling technique used was purposive sample and selected 72 unit analysis companies. The data analysis tool in this test uses OLS (ordinary least square), which wants to see the effect of audit quality and institutional ownership on the cost of debt.

Based on the results of this study indicate that audit quality has a negative effect on the cost of debt with a significance level of 0.014 which means that the company that chooses the BIG4 KAP has a good reputation and this is seen as a positive thing for the creditor. Whereas institutional ownership does not affect the cost of debt with a significance level of 0.847 indicating that the presence or absence of institutional ownership of companies - companies in Indonesia does not affect the institutional ownership relationship and the cost of debt.

Key Words: Audit Quality, Institutional Ownership and Cost of Debt.

\section{LATAR BELAKANG}

Teori keagenan menjelaskan bagaimana hubungan antara pemegang saham (prinsipal) dan manajemen (agen). Agen melakukan pengelolaan perusahaan dimana manajer bertanggung jawab terhadap pengambilan keputusan strategis dalam operasional sehari-hari perusahaan (Jensen dan Meckling, 1976). Agency Theory menjelaskan mengenai ketidaksamaan kepentingan (conflict of interest) antara principal dan agent yang dapat menimbulkan agency problem. Agency problem yang timbul antara principal dan agent disebabkan karena adanya asimetri informasi. Asimetri informasi merupakan suatu kondisi dimana pihak manajemen lebih banyak mengetahui kondisi internal perusahaan dibandingkan principal sehingga mengakibatkan konflik keagenan. Untuk meminimalisir konflik keagenan diperlukan pengawasan atau monitoring yang menyebabkan adanya agency cost. Agency cost adalah biaya yang dikeluarkan pihak prinsipal (pemegang saham) untuk meyakinkan agar agen bekerja sungguh-sungguh untuk kepentingan pemegang saham (Lukas, 1999).

Jensen (1986) berpendapat bahwa salah satu solusi untuk mengurangi konflik keagenan adalah dengan hutang, dengan adanya hutang pemegang saham dapat memonitoring kinerja manajemen. Hutang merupakan salah satu cara memperoleh dana dari pihak kreditur. Dana yang diberikan oleh kreditur dalam hal pendanaan terhadap perusahaan tersebut menimbulkan cost of debt bagi perusahaan, dimana biaya hutang (cost of debt) merupakan tingkat bunga yang diterima oleh kreditur sebagai tingkat 
pengembalian yang di syaratkan. Ketika perusahaan memutuskan investasi dan menggunakan dana dari hutang maka cost of debt perusahaan akan meningkat. Kualitas audit juga mempengaruhi cost of debt , selama ini kondisi pemantauan langsung yang dilakukan kreditur dapat menyebabkan biaya pemantauan menjadi tinggi (Prasetyo, 2013). Hal ini membuka kesempatan untuk memberikan fungsi pemantauan sepenuhnya kepada auditor. Pemantauan yang dilakukan auditor menggeser jauh fungsi pengawasan dari kreditor yang akan berpengaruh terhadap menurunnya biaya utang (cost of debt). Wahidahwati (2002), menemukan bahwa kepemilikan institusional bepengaruh negatif dan signifikan terhadap kebijakan hutang. Secara implisit kebijakan hutang merupakan suatu kebijakan yang di ambil perusahaan untuk mendanai proyek investasi atau kegiatan perusahaan dari pihak eksternal (kreditur), yang berarti bahwa dengan perusahaan melakukan kebijakan hutang maka cost of debt akan meningkat. Hasil senada dengan penelitian yang dilakukan oleh Masdupi (2005) dan Patricia (2014). Hasil penelitian berbeda dengan yang dilakukan oleh Murni dan Adriana (2007) yang menunjukan kepemilikan institusional memiliki pengaruh positif dan signifikan terhadap kebijakan hutang dimana kepemilikan institusional memiliki wewenang lebih besar dibandingkan dengan pemegang saham kelompok lain untuk cenderung memilih proyek yang lebih berisiko dengan harapan akan memperoleh keuntungan yang tinggi.

\section{LANDASAN TEORI}

\section{Teori Keagenan (Agency Theory)}

Jensen and Meckling (1976) mendefenisikan kontrak antara satu atau beberapa orang principal yang mendelegasikan wewenang kepada orang lain (agent) untuk mengambil keputusan dalam menjalankan perusahaan. Prinsip utama teori ini adalah pernyataan adanya hubungan kinerja antara pihak yang memberi wewenang (principal) seperti pemilik saham, kreditur, serta investor kepada pihak yang menerima wewenang (agent) yaitu manajemen perusahaan, dalam bentuk kontrak kerjasama.

Pelaksanaan kontrak tersebut menimbulkan biaya yang disebut agency cost, yaitu biaya yang timbul agar manajer bertindak selaras dengan tujuan pemilik, seperti pembuatan kontrak ataupun pengawasan. Dalam teori agensi, dijelaskan bahwa masalah antara principal dan agent timbul karena adanya informasi yang asimetris (information asymetry). Informasi asimetri adalah keadaan dimana informasi yang diberikan kepada principal berbeda dengan yang diberikan kepada agent untuk melakukan tindakan oportunistik. Tindakan oportunistik adalah tindakan yang tujuannya mementingkan kepentingan mereka sendiri. Hal tersebut dikarenakan manajemen perusahaan lebih mengetahui informasi internal dan prospek perusahaan di masa yang akan datang dibandingkan dengan invesor dan kreditur lainnya, Jensen and Meckling (1976).

Teori keagenan dalam kaitannya dengan biaya utang adalah merupakan salah satu solusi untuk mengurangi konflik keagenan dan peluang perusahaan untuk bertumbuh. Dengan perusahaan melakukan kebijakan hutang untuk membiaya proyek investasi dan kebutuhan operasional perusahaan, dimana kebijakan hutang akan meningkatkan biaya hutang (cost of debt) serta dengan adanya hutang perusahaan dapat memonitoring kinerja manajemen agar lebih efisien.

\section{Cost of Debt (Biaya Utang)}

Fabozzi (2007) mendefenisikan cost of debt sebagai tingkat pengembalian yang diinginkan kreditur saat memberikan pinjaman kepada perusahaan. Cost of debt dapat didefinisikan sebagai tingkat yang harus diterima dari investasi untuk mencapai tingkat pengembalian (yield rate) yang dibutuhkan oleh kreditur atau dengan kata lain adalah tingkat pengembalian yang dibutuhkan oleh kreditur saat melakukan pendanaan dalam suatu perusahaan (Fabozzi 2007).

Biaya hutang meliputi tingkat bunga yang harus dibayar oleh perusahaan ketika melakukan pinjaman. Sedangkan menurut Juniarti dan Sentosa (2009), cost of debt adalah tingkat bunga sebelum pajak yang dibayar perusahaan kepada pemberi pinjamannya. Biaya hutang dihitung dari besarnya beban bunga yang dibayarkan oleh perusahaan tersebut dalam periode satu tahun dibagi dengan jumlah pinjaman yang menghasilkan bunga tersebut. Francis et al. (2005) juga menggunakan interest rate dari hutang perusahaan untuk menghitung besarnya cost of debt yang diterima perusahaan.

Chen dan Steiner (1999) menyatakan bahwa perusahaan menggunakan utang untuk mendanai sebagian besar aset. Kebijakan utang berhubungan positif dengan risiko keuangan. Peningkatan risiko keuangan berarti menimbulkan konflik sehingga diperlukan pengaturan terhadap penggunaan hutang untuk mengurangi konflik keagenan.

Agar konflik keagenan tidak merugikan pemilik perusahaan, mekanisme yang sering ditempuh adalah dengan meningkatkan monitoring dan kontrol terhadap keputusan-keputusan manajemen. Dari sisi kreditor, transparansi manajemen akan mengurangi debt agency problem. Dengan mempertimbangkan bahwa perusahaan-perusahaan multinasional mempunyai monitoring dan kontrol yang lebih baik terhadap manajemendan juga lebih transparan, maka diharapkan perilaku manajemen 
akan lebih sesuai dengan kepentingan pemilik perusahaan. Dengan demikian maka keputusan pendnaa yang diambil diharapkan tidak akan merugikan pemilik perusahaan dan juga krediturnya.

\section{Kualitas Audit terhadap Cost of Debt}

Monitoring yang dilakukan oleh auditor dapat mengurangi agency problem karena auditor bekerja secara independen dan hasil auditnya mencerminkan kinerja manajemen sebenarnya. Tingginya suatu kualitas audit yang dihasilkan auditor dapat dilihat dari beberapa faktor, seperti sumber daya yang dimilikinya, kehati-hatian dalam melakukan aktivitas auditing, dan reputasi KAP-nya didalam pasar modal. Hasil audit dari KAP Big-4 dipandang berkualitas karena memenuhi faktor-faktor tersebut. Risiko asimetri informasi yang dihadapi perusahaan tentu akan berkurang dan dapat berakibat mengurangi cost of debt.

Pada beberapa penelitian, kehadiran auditor yang berkualitas dalam mengurangi agency problem antara agent dan principal. Penelitian yang dilakukan Kim et al, (2007) dan Lai (2011) menyatakan bahwa kualitas auditor berpengaruh negatif terhadap cost of debt dimana kreditur mengenakan biaya pinjaman lebih rendah untuk perusahaan yang diaudit KAP Big-4 daripada perusahaan yang diaudit KAP non Big-4. Perusahaan yang di audit oleh KAP Big4 memilik kecenderungan kreditur memberikan bunga pinjaman yang lebih rendah dibandingkan dengan perusahaan yang di audit oleh KAP Non Big4 karena dengan perusahaan yang di audit oleh KAP Big4 kreditur dianggap memiliki kualitas laporan keuangan terpercaya sehingga berimplikasi terhadap cost of debt perusahaan yang memberikan bunga pinjaman lebih rendah.

Sejalan dengan penelitian Kim dan Lai, Prasetyo (2013) juga menemukan kualitas auditor berpengaruh negatif terhadap cost of debt penyebabnya dimungkinkan karena KAP Big 4 lebih memiliki reputasi terpercaya dan menhasilkan laporan keuangan yang kredible dibanding dengan KAP non Big 4 oleh para kreditor, sehingga perusahaan yang menggunakan jasa KAP Big 4 dapat menurunkan cost of debt perusahaannya.

Berdasarkan uraian diatas, perumusan hipotesis dalam penelitian ini adalah:

\section{H1 : Kualitas auditor berpengaruh negatif terhadap cost of debt}

\section{Kepemilikan Institusional terhadap Cost Of Debt}

Jensen dan Meckling (1976) mengatakan bahwa apabila proporsi kepemilikan saham oleh manajer perusahaan kurang dari 100 persen merupakan awal dari agency problem, hal ini terjadi karena manajer cenderung bertindak untuk kepentingan dirinya sendiri bukan berdasarkan kepentingan dan tujuan perusahaan. Hal tersebut akan menimbulkan konfilk antar beberapa pihak yang memiliki kepentingan dalam perusahaan. konflik dapat terjadi antara manajemen dan pemilik perusahaan, antara manajer bersama-sama pemegang saham mayoritas dengan pemegang saham minoritas, antara pemegang saham dengan para kreditur, juga antara manajer dengan stakeholders lainnya.

Besarnya kontrol dari pemegang saham bergantung seberapa besar kepemilikan institusional pada perusahaan. Pemegang saham disini bertindak untuk membatasi manajemen dalam menggunakan utang. Bhoraj dan sengupta (2003) menemukan adanya hubungan negatif antara kepemilikan institusional dengan cost of debt perusahaan. Hasil penelitian Masdupi (2005) dan Patricia (2014) menunjukan kepemilikan institusional berpengaruh negatif dan signifikan terhadap biaya hutang, serta Roberts dan Yuan (2009) juga menemukan hubungan negatif kepemilikan institusional terhadap biaya hutang. Dengan demikian, kepemilikan institusional dapat mengurangi biaya utang yang diterima perusahaan.

Elyasiani et al. (2010) menyatakan bahwa kepemilikan institusional memiliki peran penting terhadap biaya hutang. Hal ini dikarenakan investor institusional berada pada posisi yang lebih baik untuk mempelajari kondisi perusahaan dan mendapat manfaat yang lebih besar. Sehingga perhatian yang diberikan investor institusional dapat menciptakan reputasi perusahaan yang lebih baik di pasar modal sehingga memungkinkan perusahaan untuk dapat memperoleh biaya hutang yang lebih rendah.

Berdasarkan uraian diatas maka dapat dikembangkan hipotesis sebagai berikut:

\section{H2 : Kepemilikan institusional berpengaruh negatif terhadap cost of debt}




\section{Kerangka Analisis}

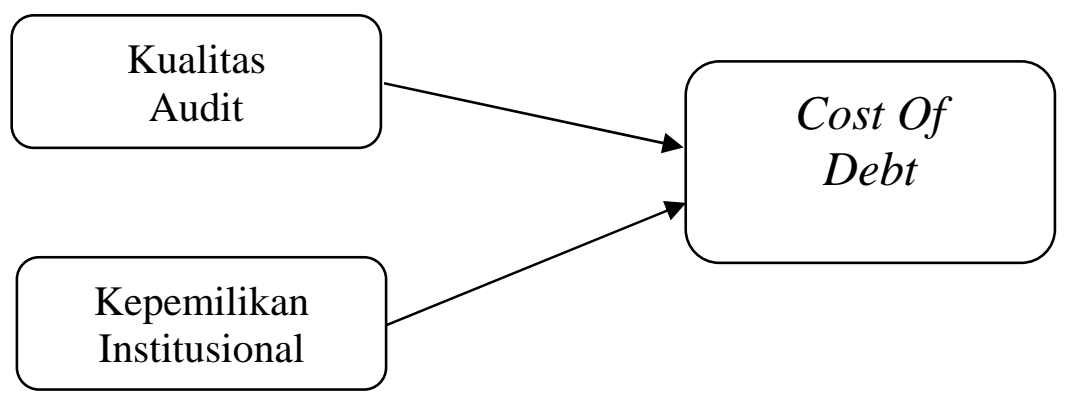

Gambar 1. Kerangka Analisis

\section{METODE PENELITIAN}

\section{Defenisi Operasional dan Pengukuran Variabel}

Dalam penelitian ini terdapat satu variabel dependen yakni cost of debt (biaya hutang) sedangkan variabel independennya yakni kualitas audit, dan kepemilikan institusional.

\section{Cost Of Debt (COD)}

Cost of Debt (COD) adalah dihitung dari besarnya beban bunga perusahaan dalam satu periode dibagi dengan jumlah rata-rata pinjaman jangka panjang dan jangka pendek yang menghasilkan bunga pinjaman selama tahun Bringham dan Houston (2001). Dalam penelitian ini rumus yang digunakan dalam penghitungan cost of debt adalah sebagai berikut:

\section{$\mathrm{COD}=\mathrm{KD}(1-\mathrm{T})$}

Ket:

KD : Beban Bunga/Rata-Rata Total Hutang

T : Tarif Pajak

Sesuai dengan tarif Pasal 17 Undang - Undang PPh, maka tarif perhitungan PPh Badan untuk tahun pajak 2010 / 2011 adalah tarif pajak tunggal 25\% dari penghasilan kena pajak. Peraturan Pemerintah ini juga merupakan amanat dari Pasal 17 ayat (2b) Undang-Undang Nomor 36 Tahun 2008 tentang Pajak Penghasilan.

\section{Kualitas Audit}

Ukuran KAP digunakan sebagai proksi untuk mengukur kualitas audit dan menggunakan pedoman penelitian Lai (2011) serta Kartiko dan Martani (2015). Ukuran KAP ini dibedakan menjadi dua yaitu untuk KAP big four dan KAP non big-four. Variabel ini diukur dengan menggunakan variabel dummy dimana angka 1 diberikan jika auditor yang mengaudit perusahaan merupakan auditor dari KAP big four dan 0 jika perusahaan diaudit oleh KAP non big four.

\section{Kepemilikan Institusional}

Proporsi kepemilikan saham yang dimiliki institusional di ukur dalam persentase saham yang dimiliki oleh investor dalam perusahaan. Fitriyah dan Hidayat (2011) serta Patricia (2014) Kepemilikan institusional merupakan kepemilikan saham perusahaan yang mayoritas dimiliki oleh institusi atau lembaga (perusahaan asuransi, bank, perusahaan investasi, asset management dan kepemilikan institusi lain).

Kepemilikan institusional dihitung dengan cara sebagai berikut:

$$
\mathrm{KI}=\frac{\text { Saham yeng dimiliki Institusional }}{\text { Jumlah Saham Beredar }}
$$

\section{Uji Asumsi Klasik Uji Normalitas}

Uji normalitas bertujuan untuk menguji apakah dalam model regresi, variabel dependen dan variabel independen mempunyai distribusi normal atau tidak (Ghozali, 2013). Alat uji yang digunakan 
adalah dengan analisis statistik non-parametic Kolmogorov-Smirnov $Z$ (1-Sample K-S) dengan menggunakan tingkat signifikansi 0,05. Data dinyatakan berdistribusi normal jika signifikansi lebih besar dari $5 \%$ atau 0,05 atau jika $\rho$ value $>0,05$ (Ghozali, 2013).

\section{Uji Multikolinearitas}

Uji multikolinearitas bertujuan untuk menguji apakah pada model regresi ditemukan adanya korelasi antar variabel bebas atau independen (Ghozali, 2013). Ini perlu dilakukan karena model regresi yang baik seharusnya tidak terjadi korelasi diantara variabel independen. Untuk mendeteksi ada tidaknya multikolinearitas di dalam model regresi adalah dengan melihat nilai tolerance dan variance inflation factor (VIF). Nilai cut off yang umum dipakai untuk menunjukkan tidak adanya multikolinieritas adalah nilai tolerance $>0,10$ atau sama dengan nilai VIF $<10$ (Ghozali, 2013).

\section{Uji Autokorelasi}

Uji ini bertujuan menguji apakah dalam model regresi linier ada korelasi antara residual pada periode $\mathrm{t}$ dengan residual pada periode $\mathrm{t}-1$ (sebelumnya). Model regresi yang baik adalah regresi yang bebas dari autokorelasi. Untuk mendeteksi ada atau tidaknya autokorelasi dapat dilihat dengan menggunakan uji Durbin-Watson (DW test). Menurut Ghozali (2013), jika nilai DW terletak diantara batas atas atau upperbound (du) dan 4 - upperbound (4-du), maka koefisien autokorelasi sama dengan nol yang berarti tidak ada autokorelasi.

\section{Uji Heterokedastisitas}

Uji heterokedastisitas bertujuan menguji apakah dalam model regresi terjadi ketidaksamaan varians dari residual satu pengamatan ke pengamatan yang lain. Jika varians dari residual satu pengamatan ke pengamatan lain tetap maka disebut homokedastisitas dan jika berbeda disebut heterokedastisitas (Ghozali, 2013). Uji heterokedastisitas dilihat melalui uji Glejser dengan ketentuan jika koefisien korelasi semua variabel terhadap residual $>0,05$ maka dapat disimpulkan model regresi tidak terjadi heterokedastisitas. Uji ini dilakukan dengan meregresikan variabel independen terhadap nilai absolut residualnya (Ghozali, 2013).

\section{Metode Analisis Data}

Alat Analisis regresi untuk mengukur besarnya pengaruh variabel bebas terhadap variabel terikat dan memprediksi variabel terikat dengan menggunakan variabel bebas, karena variabel bebas dalam penelitian ini lebih dari satu, maka analisis regresi yang digunakan adalah metode analisis ordinary least square $(O L S)$ dengan persamaan sebagai berikut:

Ket:

\section{$\mathrm{COD}=\beta 0+\beta 1 \mathrm{IOS}+\beta 2 \mathrm{KA}+\beta 3 \mathrm{JTU}+\beta 4 \mathrm{KI}+\varepsilon$}

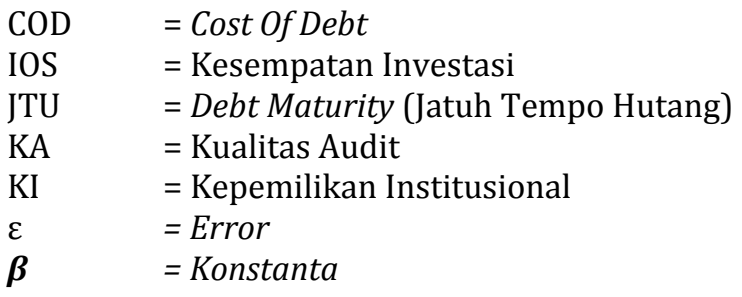

\section{HASIL PENELITIAN DAN PEMBAHASAN \\ Hasil Pengujian Asumsi Klasik Uji Normalitas Data}

Uji normalitas dilakukan dengan maksud untuk menguji apakah dalam model regresi, kedua variabel yakni variabel independen dan variabel dependen memiliki distribusi normal atau tidak (Ghozali, 2011). Dalam penelitian ini, uji normalitas yang digunakan adalah uji Kolmogorov-Smirnov dengan melihat nilai Asymp. Sig (2-tailed) dengan probabilitas 0,05. Jika nilai Asymp. Sig (2-tailed) lebih besar dari 0,05 maka data terdistribusi normal. Sedangkan jika nilai Asymp. Sig (2-tailed) lebih kecil dari 0,05 maka data l terdistribusi tidak normal. Hasil uji normalitas dirangkum dalam Tabel sebagai berikut : 
Hasil Pengujian Normalitas Data

\begin{tabular}{|c|c|c|c|}
\hline Variabel & Kolmogorov-Smirnov $\boldsymbol{Z}$ & symp. Sig. (2-tailed) & Keterangan \\
\hline COD & 2,384 & 0,000 & Tidak Normal \\
\hline KA & 6,333 & 0,000 & Tidak Normal \\
\hline KI & 8,867 & 0,000 & Tidak Normal \\
\hline
\end{tabular}

\section{Sumber: Data sekunder diolah, 2016}

Berdasarkan hasil pengujian one sampel kolmogrov smirnov (KS), terlihat bahwa semua variabel memiliki asymp. sig (2-tailed) lebih kecil dari $\alpha=0,05$ yang berarti data tidak terdistribusi normal. Langkah yang dilakukan untuk menormalkan data adalah dengan membuang data yang bersifat outlier pada casewise diagnostic dari keseluruhan observasi. Hasil transformasi data setelah membuang data yang outlier disajikan pada tabel dibawah ini :

\section{Hasil Pengujian Normalitas Data (Setelah membuang outlier)}

\begin{tabular}{|c|c|c|c|}
\hline Variabel & Kolmogorov-Smirnov $\boldsymbol{Z}$ & symp. Sig. (2-tailed) & Keterangan \\
\hline COD & 1,163 & 0,134 & Normal \\
\hline KA & 5,681 & 0,000 & Tidak Normal \\
\hline KI & 1,663 & 0,008 & Tidak Normal \\
\hline
\end{tabular}

\section{Sumber: Data sekunder diolah, 2016}

Berdasarkan hasil perbaikan data observasi menjadi 288 observasi, tabel diatas menunjukan bahwa variabel biaya utang (ost of debt) memiliki nilai asymp.sig (2-tailed) lebih besar dari 0,05 sehingga terbebas dari masalah normalitas data dan data dikatakan normal. Variabel kualitas audit (KA), dan kepemilikan institusional (KI) memiliki nilai asymp.sig (2-tailed) lebih kecil dari 0,05 dan tidak terbebas dari masalah normalitas data, meskipun telah dilakukan transformasi dengan membuang data yang outlier. Berdasarkan asumsi central limit theorem (dalil batas tengah), jika ukuran sampel digunkan cukup besar (n lebih dari 30) maka data dianggap terdistribusi normal (Dielman, 1961).

\section{Uji Autokorelasi}

Uji autokorelasi dilakukan untuk mengetahui apakah terjadi korelasi antara kesalahan pengganggu pada periode $t$ dengan kesalahan pada periode t-1. Pengujian autokorelasi dilakukan dengan melihat nilai $d$ atau koefisien Durbin Watson $(D-W)$. Hasil pengujian autokorelasi dapat dilihat di tabel dibawah ini

\section{Hasil Uji Autokorelasi}

\begin{tabular}{|c|c|c|c|c|c|c|}
\hline \multicolumn{9}{|c|}{ Pengujian autokorelasi sebelum diperbaiki } \\
\hline $\mathrm{N}$ & $\mathrm{K}$ & $\mathrm{dl}$ & $\mathrm{Du}$ & $\begin{array}{c}\text { Durbin } \\
\text { Watson }\end{array}$ & Kriteria & Keterangan \\
\hline 245 & 4 & 1,7279 & 1,8094 & 1,179 & $0<\mathrm{d}<\mathrm{dl}$ & Terkena Autokorelasi \\
\hline \multicolumn{8}{|c|}{ Pengujian autokorelasi setelah diperbaiki } \\
\hline $\mathrm{N}$ & $\mathrm{K}$ & $\mathrm{dl}$ & $\mathrm{Du}$ & $\begin{array}{c}\text { Durbin } \\
\text { Watson }\end{array}$ & Kriteria & Keterangan \\
\hline 243 & 4 & 1,7279 & 1,8094 & 2,002 & $\mathrm{du}<\mathrm{d}<4-\mathrm{du}$ & Bebas Autokorelasi \\
\hline
\end{tabular}

Sumber: Data sekunder diolah, 2016

Dengan menggunakan kriteria untuk mengetahui apakah persamaan regresi terkena masalah autokorelasi, kriteria yang terpenuhi adalah $\mathrm{du}<\mathrm{d}<4$-du sehingga disimpulkan bahwa model regresi untuk menguji hipotesis 1-4 setelah dilakukan perbaikan bebas dari masalah autokorelasi positif dan negatif. Berdasarkan hasil pengujian autokorelasi dengan menggunakan uji Durbin-Watson (DW-Test) dengan melihat nilai durbin upper dan 4-durbin upper diperoleh hasil untuk keseluruhan hipotesis bebas dari autokorelasi. 


\section{Uji Multikolinearitas}

Uji multikolinieritas dilakukan dengan tujuan untuk menguji apakah model regresi ditemukan adanya korelasi di antara variabel independen. Model dikatakan baik jika tidak terjadi korelasi di antara variabel indepeneden (Ghozali, 2011). Untuk melihat ada atau tidaknya masalah multikolinieritas dapat dilihat dari nilai Tolerance dan Variance Inflation Factor (VIF). Jika nilai tolerance $>0,1$ dan nilai VIF $<10$ maka tidak terjadi masalah multikolinieritas dan model regresi dapat dikatakan baik. Sedangkan jika nilai tolerance $<0,1$ dan nilai $V I F>10$ maka terjadi masalah multikolinieritas. Hasil uji multikolinieritas untuk pengujian tanpa variabel kontrol dapat dilihat pada tabel berikut ini :

\section{Hasil Uji Multikolinieritas}

\begin{tabular}{|l|c|c|c|}
\hline \multirow{2}{*}{ Variabel } & \multicolumn{2}{|c|}{ Collinearity Statistics } & \multirow{2}{*}{ Keterangan } \\
\cline { 2 - 3 } & Tolerance & VIF & Bebas dari multikolearitas \\
\hline IOS & 0,709 & 1,410 & Bebas dari multikolearitas \\
\hline KA & 0,761 & 1,314 & Bebas dari multikolearitas \\
\hline JTU & 0,990 & 1,010 & Bebas dari multikolearitas \\
\hline KI & 0,883 & 1,132 & \\
\hline
\end{tabular}

\section{Sumber: Data sekunder diolah, 2016}

\section{Uji Heterokedastisitas}

Pengujian heteroskedastisitas bertujuan untuk menguji apakah dalam model regresi terjadi ketidaksamaan variance dari residual satu observasi ke observasi yang lain. Dalam penelitian ini untuk menguji heteroskedastisitas digunakan uji glejser yang dilakukan dengan meregresikan variabel-variabel bebas terhadap nilai absolut residualnya (Ghozali, 2011). Hasil uji heteroskedastisitas pada tabel dibawah ini:

\section{Hasil Uji Heteroskedastisitas}

\begin{tabular}{|l|c|c|c|c|}
\hline Variabel & Koefisien & $\mathrm{t}$ & Sig. & Keterangan \\
\hline Konstanta & 0,015 & 3,320 & 0,001 & Bebas Heteroskedastisitas \\
\hline IOS1 & $-2,088$ & $-0,062$ & 0,950 & Bebas Heteroskedastisitas \\
\hline KA & $-0,002$ & $-0,963$ & 0,336 & Bebas Heteroskedastisitas \\
\hline JTU1 & 0,009 & 1,605 & 0,110 & Bebas Heteroskedastisitas \\
\hline KI1 & 0,012 & 1,475 & 0,141 & Bebas Heteroskedastisitas \\
\hline F & 1,510 & & & \\
\hline Sig. & 0,200 & & & \\
\hline
\end{tabular}

Sumber: Data sekunder diolah, 2016

\section{Pengujian Hipotesis}

Penelitian ini bertujuan untuk menjelaskan pengaruh kualitas auditor, dan kepemilikan institusional terhadap cost of debt. Hipotesis penelitian ini diuji dengan menggunakan OLS (ordinary least square). Hipotesis penelitian ini terdiri dari empat hipotesis. Dalam pengujian setiap hipotesis akan dilakukan secara bersama-sama pada tabel sebagai berikut:

\section{Hasil Pengujian Hipotesis}

\begin{tabular}{|l|c|c|c|c|}
\hline \multicolumn{1}{|c|}{ Variabel } & Koefisien & $\boldsymbol{t}$ & Sig. & Keterangan \\
\hline Konstanta & 0,038 & 5,159 & 0,000 & \\
\hline KA & $-0,010$ & $-2,485$ & 0,014 & H2 diterima \\
\hline KI1 & $-0,003$ & $-0,193$ & 0,847 & H4 ditolak \\
\hline R Square & 0,055 & & & \\
\hline Adjusted R Square & 0,037 & & & \\
\hline F & 3,482 & & & \\
\hline Sig & 0,009 & & & \\
\hline
\end{tabular}

\section{Sumber: Data sekunder diolah, 2016}




\section{Pengaruh Kualitas Audit terhadap Cost of Debt}

Hipotesis dua pada penelitian menyatakan bahwa kualitas audit berpengaruh negatif dan signifikan terhadap biaya hutang. Berdasarkan pengolahan data yang telah dilakukan. Variabel kualitas audit di ukur dengan menggunakan variabel dummy dengan memberikan angka 1 untuk perusahaan di audit oleh KAP BIG4 dan 0 jika perusahaan tidak di audit oleh KAP Non BIG4. Menunjukan hasil yang signifikan yang berarti variabel kulitas audit diterima. Dengan demikian terdapat hubungan signifikan yang berarti variabel kualitas audit memiliki pengaruh negatif terhadap cost of debt.

Hasil penelitian ini sejalan dengan penelitan Juniarti dan Sentosa (2009) yang menyatakan kualitas audit berpengaruh negatif dan signifikan terhadap cost of debt. Menurut Juniarti dan Sentosa (2009) semakin besar kualitas audit, maka cost of debt perusahaan semakin kecil. Hasil penelitian Lai (2011) juga menemukan hasil bahwa kualitas audit berpengaruh negatif signifikan terhadap cost of debt, dengan perusahaan yang di audit oleh KAP BIG4 dianggap perusahaan lebih memiliki laporan keuangan yang berkualitas. Prasetyo (2013) juga menemukan bahwa kualitas audit memiliki pengaruh negatif signifikan terhadap cost of debt. Nugroho dan Meiranto (2014) jugan menemukan hasil penelitiannya yang menjelaskan bahwa kualitas audit berpengaruh negatif dan signifikan terhadap cost of debt.

\section{Pengaruh Kepemilikan Institusional terhadap Cost of Debt}

Berdasarkan hasil pengujian hipotesis keempat dapat disimpulkan bahwa kepemilikan institusional tidak berpengaruh terhadap cost of debt. Penelitian ini sejalan dengan penelitian Nurmasari (2015) yang menemukan bahwa kepemilikan institusional tidak berpengaruh terhadap cost of debt, dibuktikan dengan nilai koefisien sebesar $-0,718$ pada nilai signifikansi 0,133 . Penelitian Nurmasari (2015) menunjukkan bahwa persentase kepemilikan institusional yang cukup besar tidak mampu menjadi pengontrol atas penggunaan hutang, sehingga tidak berpengaruh terhadap cost of debt perusahaan. Kepemilikan institusional berkonsentrasi pada penanaman modal dalam perushaan dan tidak terlibat pada proses pengambilan keputusan yang dilakukan manajemen.

Penelitian Safitri (2015) juga menemukan hasil bahwa kepemilikan institusional tidak berpengaruh terhadap cost of debt, karena kepemilikan institusional berlaku sebagai pengawas terhadap kinerja manajemen dan manajemen dianggap sebagai pihak yang lebih mengerti terhadap kebutuhan pendanaan didalam perusahaan sehingga kepemilikan institusional bertindak sebagai pencegahan terhadap pemborosan yang dilakukan manajemen. Kepemilikan institusional yang berlaku cukup besar sebagai pengawas dapat mengurangi konflik agensi karena dapat memonitor secara langsung kinerja manajemen.

Jadi dapat disimpulkan bahwa ada atau tidaknya kepemilikan institusional perusahan perusahaan di Indonesia tidak mempengaruhi hubungan kepemilikan intitusional dan cost of debt, dimana hal ini dikarenakan struktur kepemilikan di Indonesia yang masih belum jelas antara kepemilikan dan kontrol, sehingga menyebabkan fungsi kepemilikan sebagai monitor dan pengawasan terhadap kinerja manajemen dan fungsi kepemilikan untuk mencegah agency cost tidak berjalan dengan baik. Persentase kepemilikan institusional yang cukup besar tidak mampu menjadi pengontrol atas penggunaan hutang, karena pihak manejemen dianggap lebih mengetahui keputusan apa yang harus diambil dalam proses keputusan investasi, kepemilikan institusional hanya dijadikan pengawas terhadap kinerja manajemen sehingga dapat mengurangi konflik keagenan antara agent dan principal.

\section{KESIMPULAN}

Pada dasarnya tujuan penelitian ini menguji secara empiris mengenai pengaruh set kesempatan investasi (IOS), kualitas audit, jatuh tempo hutang, dan kepemilikan institusional terhadap cost of debt. Berdasarkan hasil yang diperoleh dari pengolahan dan analisis data dengan menggunakan analisis OLS (ordinary least square) dengan bantuan alat SPSS 16.0, maka dapat diambil kesimpulan sebagai berikut :

1. Kualitas audit terbukti memiliki pengaruh terhadap cost of debt. Perusahaan yang memilih KAP BIG4 yang memiliki reputasi yang baik dan ini dipandang sebagai hal positif bagi pihak kreditur karena perusahaan tersebut di nilai lebih transparan, dan memiliki kualitas laporan keuangan yang baik, sehingga risiko perusahaan menjadi lebih rendah dan pihak kreditur memberikan bunga pinjaman rendah yang berdampak pada cost of debt perusahaan semakin kecil.

2. Kepemilikan institusional tidak terbukti memiliki pengaruh terhadap cost of debt. Menjelaskan bahwa ada atau tidaknya kepemilikan institusional perusahan - perusahaan di Indonesia tidak mempengaruhi hubungan kepemilikan intitusional dan biaya utang. 


\section{DAFTAR PUSTAKA}

Bringham, Eugene F, dan Houston, Joel F, (2001). Manajemen Keuangan. Edisi 8. Jakarta: Erlangga. Hal. 407

Elyasiani, E. J. Jia and C. X. Mao. (2010). Institusional Ownership Stability and The Cost Of Debt. Journal of Financial Markets. 13, Hal.475-500.

Fabozzi, F.J. (2007). Bond markets, analysis, and strategies (ed.8). New Jearsey: Prentice Hall.

Fitriyah, Fury K dan Hidayat, Dina. (2011). Pengaruh Kepemilikan Institusional, Set Kesempatan Investasi, Dan Arus Kas Bebas Terhadap Kebijakan Hutang. Jurnal Media Riset Akuntansi, vol.1 (1).

Ghozali, Prof. Dr. Imam M. Com., Akt. (2013). Aplikasi Analisis Multivariate dengan Program IBM SPSS 21, Update PLS Regresi.Edisi 7. Semarang: Badan Penerbit Universitas Diponegoro.

Ikatan Akuntan Indonesia (2014). PSAK no.26. Biaya Pinjaman. Jakarta: Graha Akuntan

Jensen, MC dan William H Meckling. (1976). Theory of The Firm : Managerial Behaviour, Agency Cost, and Ownership Structure. Journal of Financial Economics, Juli 1976, Vol. 3 Hal.305-360.

Juniarti \& A.A. Sentosa. (2009). Pengaruh Corporate Governance dan Voluntary Disclosure terhadap Biaya Hutang (Cost of Debt). Jurnal Akuntansi dan Keuangan, Vol. 11, No. 2, Hal.88-100.

Kartiko, Sigit Wahyu dan Dwi Martani. (2015). Peran Implisit Kualitas Audit dalam Menekan Perilaku Tax Avoidance. Simposium Nasional Akuntansi 18, Medan 16-19 September 2015.

Kim. J. B., B. Y. Song., \& J. S. L. Tsui. (2007). Auditor Quality, Tenure, and Bank Loan Pricing. Working Paper, Hongkong Polytechnic University.

Lai, Kam-Wah. (2011). The Cost of Debt When All-Equity firms Raise finance: The Role Of Investment Opportunities, Audit Quality And Debt Maturity. Journal Of Banking \& Finance 35, 2011. Hal.1931-1940

Murni, Sri Dan Adriana., (2007). Pengaruh Insider Ownership, Institusional Investor, Deviden Payment, Dan Firm Growth Terhadap Kebijakan Hutang Perusahaan (Studi Kasus Pada Perusahaan Manufaktur Yang Terdaftar di Bursa Efek Jakarta), Jurnal Akuntansi Dan Bisnis, Vol. 7 No. 1, Februari, Hal.15-24.

Myers, S. (1977). “Determinants of Corporate Borrowing”, Journal of Financial Economics 5, PP. 147-176.

Nurmasari, Nuraini Desty (2015). Pengaruh kepemilikan manajerial, kepemilikan Institusional, kebijakan dividen, pertumbuhan Perusahaan, dan profitabilitas terhadap Kebijakan hutang perusahaan (studi empiris pada perusahaan manufaktur yang terdaftar Di bursa efek indonesia). Skripsi, Fakultas Ekonomi, Universitas Negeri Yogyakarta. Tidak Diterbitkan

Patricia, Mayang, (2014). Pengaruh Kepemilikan Institusional, Kepemilikan Manajerial, Set Kesempatan Investasi, Dan Arus Kas Bebas Terhadap Kebijakan Hutang Perusahaan. Skripsi tidak dipublikasikan. Semarang. Fakultas Ekonomi Dan Bisnis Universitas Diponegoro.

Prasetyo, Rian Eko Dan Raharja, Surya. (2013). Analisis Pengaruh Kualitas Auditor Dan Komite Audit Terhadap Cost Of Debt Dengan Usia Perusahaan Sebagai Variabel Pemoderasi (Studi Pada Perusahaan Yang Melakukan Ipo Di Bei Tahun 2008-2012). Diponegoro Journal Of Accounting. ISSN (Online): 2337-3806, Vol. 2, No. 3, Thn 2013, Hal. 1-12

Roberts, G. S. dan L. Yuan. (2009). Doest Institusional Ownership Affect The Cost of Bank Borrowing? Working Paper. York Univesity.

Safitri, Indah. (2015). Pengaruh Kepemilikan Institusional Dan Free Cash Flow terhadap Kebijakan Hutang. Jurnal Ilmu \& Riset Akuntansi, Vol.4 No.7

Wahidawati. (2002), Pengaruh Kepemilikan Manajerial Dan Kepemilikan Institusional Pada Kebijakan Hutang Perusahaan: Sebuah Perspektif Theory Agency, Jurnal Riset Akuntansi Indonesia, Vol.5, No.1, Hal 1-16. 